\title{
Study on Relay System Performance of Simulation Platform Based on LTE-A
}

\author{
Zhen Zhang, Huaidong Xu, Yan Gu, Chenming Li ${ }^{*}$ \\ College of Computer and Information Engineering, \\ Hohai University, Nanjing, China \\ E-mail: zz_hhuc@163.com \\ *Corresponding Author
}

\begin{abstract}
Relay technology is an important technical means to achieve a smooth transition from Long Term Evolution (LTE) to LTE-Advanced (LTE-A). Theoretically, the addition of nodes will improve the performance of the system effectively. While the relay is active nodes, addition of nodes become a new source of interference. Based on the LTE-A simulation platform, the effect of relay node on the system is analyzed.
\end{abstract}

Keywords- relay technology; simulation analysis; system performance

\section{INTRODUCTION}

The spectrum resource for wireless communication is more valuable than that for wire commutation. Currently, the transmission of large data has been preferred. In order to obtain high system capacity in the existing condition, a large number of spectrum resources are concentrated in higher frequency bands. But the higher frequency band will produce large path loss and higher penetration loss. This will reduce the communication quality. The introduction of relay technology in R10 will solve this problem well. Many operators and equipment manufacturers also be the focus on this technology [1-4].

Simply, the relay is a new node which is placed between the middle of the original base station and mobile phone communication and become a bridge of communication. From the base station, the relay is mobile phone terminal. And from the mobile terminal, the relay is a new base station [5-9].

The relay technology brought many benefits to the current system:

-Reduce the cost of network layout. As the relay acts as a bridge, the effective scope of the base station is enlarged. You can reduce the investment and enlarge communication range.

- Suitable for emergency communications. As relay nodes are more flexible and easy to layout, under special conditions they can play a crucial role in the Wenchuan earthquake, Zhouqu mudslides and other disasters, relay communications as emergency communications, played a crucial role.

\section{THE EFFECT OF RELAY TO LTE-A SYSTEM}

Relay technology is an important technical means to achieve a smooth transition from Long Term Evolution (LTE) to LTE-Advanced (LTE-A). Theoretically, the addition of nodes will improve the performance of the system effectively. While the relay is active nodes, addition of nodes become a new source of interference. Based on the LTE-A simulation platform, the effect of relay node on the system is analyzed. The basic parameters of the simulation platform are shown in TABLE I.

TABLE I. THE BASIC PARAMETERS OF THE SIMULATION PLATFORM

\begin{tabular}{|c|c|}
\hline Options & Values \\
\hline $\begin{array}{ll}\text { Carrier } & \text { center } \\
\text { frequency } & \end{array}$ & $2.0 \mathrm{GHz}$ \\
\hline System bandwidth & $5 \mathrm{MHz}$ \\
\hline $\begin{array}{l}\text { The number of cells / } \\
\text { number of sectors }\end{array}$ & 10 \\
\hline $\begin{array}{l}\text { MUE (Each User of } \\
\text { E-base station) }\end{array}$ & 5 \\
\hline $\begin{array}{l}\text { The number of each } \\
\text { cell relay }\end{array}$ & 2 \\
\hline $\begin{array}{l}\text { Time division } \\
\text { multiplexing uplink } \\
\text { and downlink } \\
\text { configuration options }\end{array}$ & Configuration $0 \sim 6$ \\
\hline Path loss & $\begin{array}{l}\text { Macro to Relay: } \\
\text { PLLOS(R) }=100.7+23.5 \log 10(\mathrm{R}) \\
\text { Macro to UE:L }=128.1+37.6 * \log 10(\mathrm{R}) \\
\text { Relay to UE: PLLOS(R) }=103.8+20.9 \log 10(\mathrm{R})\end{array}$ \\
\hline Shadow distribution & Macro to Relay: $6 \mathrm{~dB}$; Relay to UE: $10 \mathrm{~dB}$ \\
\hline $\begin{array}{l}\text { Shading correction } \\
\text { parameters }\end{array}$ & 0.5 (between cells), 1 (between sectors) \\
\hline Through the wall loss & Macro to Relay: 0 ;Relay to UE: $20 \mathrm{~dB}$ \\
\hline $\begin{array}{l}\text { Base station antenna } \\
\text { models }\end{array}$ & $\begin{array}{l}A_{H}(\varphi)=-\min \left[12\left(\frac{\varphi}{\varphi_{3 \mathrm{~dB}}}\right)^{2}, A_{m}\right], \\
A_{m}=20, \quad \phi_{3 \mathrm{~dB}}=70^{\circ}\end{array}$ \\
\hline Relay antenna model & Omnidirectional antenna $A(\theta)=0 \mathrm{~dB}$ \\
\hline Noise Coefficient & $5 \mathrm{~dB}$ \\
\hline User Mobility & $3 \mathrm{Km} / \mathrm{h}$ \\
\hline $\begin{array}{l}\text { The number of } \\
\text { antennas of the user } \\
\text { and the base station }\end{array}$ & Tx1/Rx2 with MRC (maximum ratio combing) \\
\hline $\begin{array}{l}\text { Base station / } \\
\text { repeater / user } \\
\text { antenna gain }\end{array}$ & $7 \mathrm{dBi} / 5 \mathrm{dBi} / 0 \mathrm{dBi}$ \\
\hline $\begin{array}{l}\text { User maximum } \\
\text { transmit power }\end{array}$ & $24 \mathrm{dBm}$ \\
\hline Business model & full buffer \\
\hline
\end{tabular}


In the baseline scenario, seven plots were set up in each cell three sectors, each placed two relay nodes relay node on the system performance, first from the perspective of throughput. The relay platform user throughput maps are shown in the Figure 1:

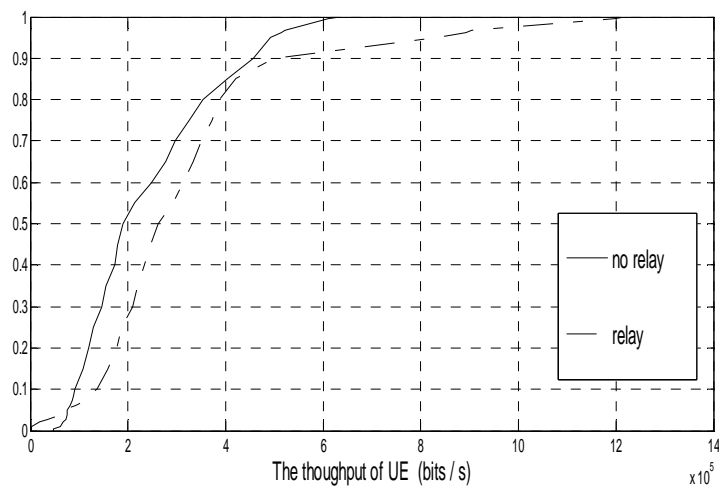

Figure 1. The relay platform user throughput maps

Where, the benchmark program parameters include: the number of the Un port is 1:3; The scheduling RB number of each user is assigned to $4 \mathrm{RB}$. The relay node platforms throughput simulation results of statistical is shown in the Table II:

TABLE II. THE RELAY NODE PLATFORMS THROUGHPUT SIMULATION RESULTS OF STATISTICAL

\begin{tabular}{|c|c|c|c|c|}
\hline & $\begin{array}{c}\text { No relay } \\
\text { platform } \\
\text { system }\end{array}$ & $\begin{array}{c}\text { Relay } \\
\text { platform } \\
\text { system }\end{array}$ & $\begin{array}{c}\text { Access link } \\
\text { from } \\
\text { Repeaters }\end{array}$ & $\begin{array}{c}\text { Access link } \\
\text { from base } \\
\text { station }\end{array}$ \\
\hline $\begin{array}{c}\text { Average user } \\
\text { throughput } \\
\text { (Mbit/s) }\end{array}$ & 0.24 & 0.31 & 0.93 & 1.45 \\
\hline $\begin{array}{c}\text { System/link } \\
\text { throughput } \\
\text { (Mbit/s) }\end{array}$ & 4.8 & 6.2 & 9.3 & 2.9 \\
\hline $\begin{array}{c}\text { Edge user } \\
\text { throughput }\end{array}$ & 0.096 & 0.12 & $\begin{array}{c}\text { Not } \\
\text { statistics }\end{array}$ & $\begin{array}{c}\text { Not } \\
\text { statistics }\end{array}$ \\
\hline $\begin{array}{c}\text { Spectrum } \\
\text { utilization } \\
(\%)\end{array}$ & 0.96 & 1.24 & 1.86 & 0.58 \\
\hline \multicolumn{2}{|c}{} & \multicolumn{2}{|c}{} \\
\hline
\end{tabular}

CDF curve from the throughput of the system point of view, the relay makes the system performance is improved. Statistics, we see that the access link throughput reached a $9.3 \mathrm{Mbit} / \mathrm{s}$, while the throughput of the return link for $2.9 \mathrm{Mbit} / \mathrm{s}$ which means that a large amount of data is uploaded to the relay by RUE relay uploading data to the base station was slowed considerably. It can be foreseen that the relay node ability to transmit data to the base station will determine the communication quality of the entire system.

\section{Un PROT TIME-FREQUENCY RESOURSES RE- ALLOCATION}

The ability of relay nodes to send data to the base station becomes a bottleneck restricting the performance of the system. We will adjust the Un port time-frequency resources, to further improve the system performance. Improvement program are as follows:

TABLE III. TIME-FREQUENCY PROGRAM

\begin{tabular}{|l|c|c|}
\hline & Un port timeslot & $\begin{array}{c}\text { Un port Relay allocate } \\
\text { resource blocks }\end{array}$ \\
\hline $\begin{array}{l}\text { Improvement } \\
\text { program I: }\end{array}$ & $1: 3$ & $8 \mathrm{RB}, 12 \mathrm{RB}$ \\
\hline $\begin{array}{l}\text { Improvement } \\
\text { program II: }\end{array}$ & $2: 2$ & $4 \mathrm{RB}$ \\
\hline
\end{tabular}

\section{A. Un Port Frequency Resourses Re-allocation}

Benchmark programs, the obtained user $4 \mathrm{RBs, \text {good }}$ performance of the relay, and the UE is allocated the same number of RB's, the performance advantage can not be embodied as an improved scheme a, we will be assigned to the scheduling relay $8 \mathrm{RB} / 12 \mathrm{RB}$. The simulation results are as follows:

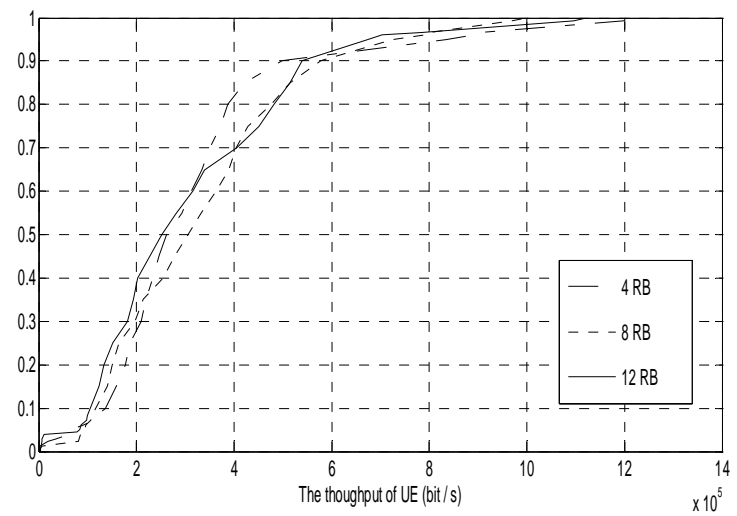

Figure 2. Un port allocated frequency domain resource adjustments user throughput distribution

TABLE IV. UN PORT DIFFERENT FREQUENCY DOMAIN RESOURCE THROUGHPUT SIMULATION RESULTS

\begin{tabular}{|c|c|c|c|}
\hline $\begin{array}{c}\text { Average user } \\
\text { throughput } \\
\text { (Mbit/s) }\end{array}$ & $4 \mathrm{RB}$ & $8 \mathrm{RB}$ & $12 \mathrm{RB}$ \\
\hline MUE+RUE & 0.31 & 0.34 & 0.32 \\
\hline MUE & 0.37 & 0.31 & 0.24 \\
\hline RUE & 0.27 & 0.36 & 0.43 \\
\hline $\begin{array}{c}\text { Access link } \\
\text { (10rue) }\end{array}$ & 0.93 & 0.94 & 0.93 \\
\hline $\begin{array}{c}\text { Backhaul } \\
\text { links (2Relay) }\end{array}$ & 1.45 & 1.84 & 2.15 \\
\hline
\end{tabular}

Un port different frequency domain resource throughput simulation results is shown in Table IV. Un port frequency domain resources to be re-allocated, the following conclusions:

- Un port to adjust the number of resources, Un port every time allocated $8 \mathrm{RB}$ contains MUE, and RUE average user throughput reaches $0.34 \mathrm{mbps}$ Un port every time allocated $12 \mathrm{RB}$ the average throughput of all users of $0.32 \mathrm{mbps}$, compared to the baseline 
scenario $0.31 \mathrm{mbps}$, a gain of $6.5 \%$ and $3.2 \%$, respectively.

- $\quad$ The Un port resource block allocation increase MUE throughput dropped compared to the baseline scenario. The Un port allocated eight RB in each time, and allocated $12 \mathrm{RB}$ MUE average user throughput decreased $16.2 \%, 35.1 \%$. Because the general relay is an active node, and the occurrence of relatively large power, there will be a higher SINR to noise ratio, so that the competition of the MUE to grab the resource block, and above that of said the Un interface resource block increased, MUE reduction in Un port access to resources, therefore, each assigned to Un port greater resource block, the lower the MUE average throughput drop. Corresponding RUE average throughput will be with the forward each time Un port number of resource blocks assigned to the increased and improved. Seen from the foregoing sections, the access link in good condition, a large number of Rue pass data to the base station end, a Since the RUE uploaded data relaying is required to be forwarded, so the increase Un port each assigned to the resource block size after the corresponding relay upload data capacity has been improved, the average throughput of the link from Table speaking, rue average throughput and post back with each increase in the number of resource blocks allocated to Un port increase, wherein Un port the each allocation eight $\mathrm{RB}$, and each allocated 12 RB RUE average user throughput increased by $33 \%$ and $59.3 \%$, respectively.

- From the whole system point of view, each assigned to the Un-port 8 resource blocks, the performance of the overall gain of $6.5 \%$, while each assigned to port $12 \mathrm{RB}$ Un system performance gains of only $3.2 \%$. This is appropriate because every time allocated to the Un-port $8 \mathrm{RB}$ reduce MUE throughput, relatively efficient to solve the bottleneck problem of the relay, balanced MUE and relay occupied resources. And each assigned to Un port $12 \mathrm{RB}$ more efficient to solve the bottleneck problem of the relay, but it does too much to seize the resources of the MUE.

- As a whole system, we need not only to the average user throughput of the whole system is improved, but also to balance the relationship between the macro users and relay user. Un port allocates $8 \mathrm{RB}$ program done on several programs each time, to enhance overall system performance, and also take care of the balance between the different types of users, better feasibility in the existing conditions.

\section{B. Un Port Time Resourses Re-allocation}

In the baseline scenario, Un port only one uplink channel Un port three up3tream channels. Improvement program, we will increase the Un port uplink channel number to two. The simulation results are shown in figure 3 :

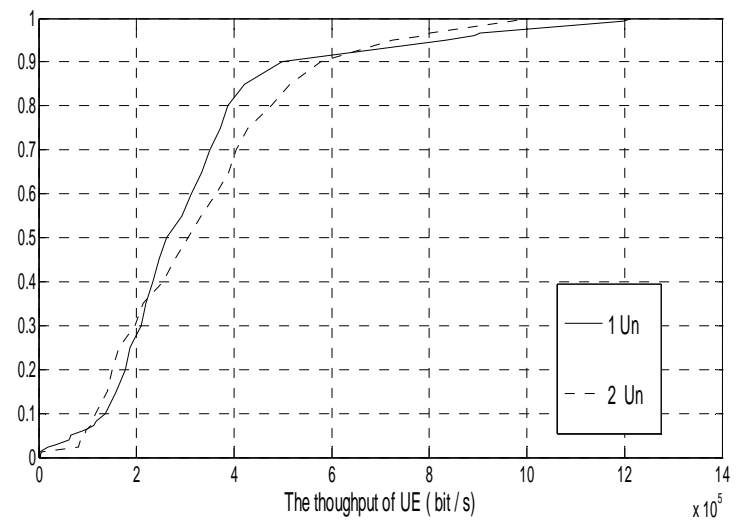

Figure 3. The Un ports which are no in th5 same domain resource allocation user throughput distri"ution

$\mathrm{T}$ (e statistics results of the Un ports which are in the same domain resource allocation scheme is shown in table $\mathrm{v}$ :

TABLE V. THE STATISTICS RESULTS OF THE UN PORTS WHICH ARE IN THE SAME DOMAIN R\%SOURCE !LLOCATION SCHEME（MBIT/S）

\begin{tabular}{|c|c|c|}
\hline throughput & $\begin{array}{c}\text { Configure one Un } \\
\text { port }\end{array}$ & $\begin{array}{c}\text { Configure two Un } \\
\text { ports }\end{array}$ \\
\hline $\begin{array}{c}\text { Average user } \\
\text { throughput }\end{array}$ & 0.31 & 0.36 \\
\hline $\begin{array}{c}\text { System } \\
\text { throughput }\end{array}$ & 0.62 & 0.72 \\
\hline MUE throughput & 0.37 & 0.36 \\
\hline RUE throughput & 0.27 & 0.35 \\
\hline $\begin{array}{c}\text { Average throughput of } \\
\text { the access link users }\end{array}$ & 0.93 & 0.92 \\
\hline $\begin{array}{c}\text { Return link users average } \\
\text { throughput }\end{array}$ & 1.45 & 1.82 \\
\hline
\end{tabular}

Analysis of simulation results:

- $\quad$ Adjust the system time slot configuration, increased a Un port channels, the corresponding a Un port less channel, the overall performance of the system has improved, an Un port when the average user throughput reached $0.31 \mathrm{mbps}$ and configure two Un port, the gap average user throughput reaches $0.36 \mathrm{mbps}$, a $16.1 \%$ increase.

- The Un port slot configuration change has little effect on the MUE, the average throughput decreased slightly from $0.37 \mathrm{mbps}$ down $0.36 \mathrm{mbps}$ down $2.8 \%$. This is because Un port and Un port divided mainly for relay whom access link and a backhaul link, the MUE can uplink transmission data in these two channels moment.

- Access link by RUE uploaded to relay link conditions are essentially the same, the change of the average user throughput of the access link. However, due to the reduction of the Un port slots, so that the opportunity RUE upload data is reduced, so the total amount of data of the access link Add reduce. However, due to the high quality of the access link channel conditions, and therefore will not have to return link performance impact. 
- Relay the bottleneck problem due to the increase the Un port number of slots, from the time domain to improve the return link to upload the amount of data increases, the average user throughput backhaul link $1.82 \mathrm{mbps} 1.45 \mathrm{mbps}$ rise to improved by $25.5 \%$, a slight increase in the overall system performance.

\section{CONCLUSION}

Completed with relay node platform, the maximum carrier to interference ratio, polling, and proportional fair algorithm are simulated. We verified the maximum throughput of the system based on the carrier to interference ratio algorithm, but the algorithm is unfair. Resource allocation based polling algorithm system has close opportunity and has the highest coefficient of fairness, but the lowest system throughput is lowest. Proportional fair algorithm is most commonly used in the actual system because it has both system throughput and user fairness.

System platform based on the proportional fair resource allocation algorithm evaluated the Relay node of the system. Through the simulation experiments, the entire system can play better. Since the allocation of resources as used in study does not give relay node Un tendency port in the timefrequency resources. This has significant bottlenecks that occur between the access link and backhaul link which connected large amounts of data into the link stranded in Relay-side.

From the simulation results, the increase in the frequency domain resources program with Un port, can effectively improve the Relay bottlenecks, However, due to the overall system bandwidth must operate blindly, if increase the frequency domain of the Un resources would affect the system macro user the communication quality. Therefore the increase of the frequency-domain resources Un port needs to consider the balance between the Relay bottleneck problem and the system throughput. From the simulation results, increasing the time domain Un port can remove the bottleneck caused by the system throughput.

\section{REFERENCES}

[1] I. Nicola, Art Dewulf and Claudia Pahl-Wostl. Making framing of uncertainty in water management practice explicit by using a participant-structured approach, Journal of Environmental Management, 2010, 91(4), 32-39.

[2] N. Zapata, I. Chalgaf, E. Nerilli, B. Latorre, C. López, A. Martínez-Cob, J. Girona, E. Playán, Software for on-farm irrigation scheduling of stone fruit orchards under water limitations Original Research Article Computers and Electronics in Agriculture, 2012(08), 52-62.

[3] L.M. Zeng, R.Z Han. Modeling and Analyzing of Simulation in Emergency Resource Scheduling, Journal of System Simulation, 06, 2012, 12-17.

[4] R. Agnieszka, R. Radosław, A note on optimization in deteriorating systems using scheduling problems with the aging effect and resource allocation models Original Research Article, Computers \& Mathematics with Applications, 2011, 62(4), 18701878.

[5] D. Furong, D. Zengchuan, and F. Qunfang, Study on the model of optimal allocation of water resources in reception basin about interbasin water transfers, Water Resources Journal Supplement, 2007(08), 485-489

[6] L. Guowei, Thinking of South-to-North Water Transfer of China, Advances in Water Science, 2000, 11(03), 345-350.

[7] L. Qin, Plain river network hydraulic calculation and gates Flood system optimization scheduling. Hohai University, 2006

[8] T. Jinghuan, L. Fangfang, The river flood Evolution Analysis and mathematical model of one-dimensional. China Water Transport (Academic Edition), 2007(08), 94-95.

[9] X. ZhiHui, L. Xikun, C. Jihua, Hardware/Software Partitioning Based on Dynamic Combination of Genetic Algorithm and Ant Algorithm, Journal of Software. 2005(4), 503-512. 